\title{
Gambaran Self Care pada Pasien Paska Stroke di Wilayah Kerja Puskesmas Kedungmundu Semarang
}

\author{
Ayu Martha Puri ${ }^{1}$, Dody Setyawan ${ }^{2}$ \\ ${ }^{I}$ Mahasiswa Departemen Ilmu Keperawatan, Fakultas Kedokteran, Universitas Diponegoro, \\ Semarang, Indonesia (email: ayumarta46@gmail.com) \\ ${ }^{2}$ Staf Pengajar Divisi Keperawatan Dewasa, Departemen Ilmu Keperawatan, Fakultas \\ Kedokteran, Universitas Diponegoro, Semarang, Indonesia (email: \\ dody.psikfkundip@gmail.com) \\ Corresponding Author: dody.psikfkundip@gmail.com
}

\begin{abstract}
Abstrak
Stroke merupakan suatu kegawatan yang menyerang neurologis secara mendadak yang menjadi salah satu penyebab kecacatan dan kematian tertinggi di dunia. Pasien pasca stroke harus melakukan self care untuk mencegah rehospitalisasi, komplikasi, dan stroke berulang. Tujuan penelitian ini untuk mengetahui gambaran self care pada pasien pasca stroke. Penelitian ini menggunakan penelitian survei deskriptif kuantitatif. Teknik pengambilan sampel yang digunakan adalah total sampling. Responden penelitian ini adalah 79 pasien pasca stroke yang berobat jalan di Puskesmas Kedungmundu Semarang. Data diambil dengan menggunakan Kuesioner Self Care Paska Stroke dan dianalisis dengan statistik deskriptif. Hasil penelitian menunjukkan bahwa lebih dari setengah responden memiliki self care yang baik (57\%) dan kurang baik (43\%).Peneliti menyarankan bahwa tenaga kesehatan harus secara aktif berkolaborasi dengan pasien pasca stroke untuk memberikan motivasi dalam melakukan perawatan diri.
\end{abstract}

Kata kunci : paska stroke, self care

\begin{abstract}
Stroke is a sudden onset of neurological attack which is one of the highest causes of disability and death in the world. Post-stroke patients must do self-care to prevent rehospitalization, complications, and recurrent stroke. The aim of this research is to know the overview of self care in post-stroke patients. This research used a quantitative descriptive survey research. The sampling technique used is total sampling. Respondents of this study were 79 post-stroke patients who outpatient in Puskesmas Kedungmundu Semarang. The data was taken by using the Questionnaire Self Care Post Stroke and was analyzed by using descriptive statistic. The result showed that more than half of the respondents have good self care (57\%) and less good (43\%). Researchers suggest that paramedics have to actively collaborate with post stroke patients to provide motivation in doing selfcare.
\end{abstract}

Keywords : post-stroke, self care 
Jurnal Ilmu Keperawatan Medikal Bedah 3 (1), Mei 2020, 1-76

ISSN 2338-2058 (print), ISSN 2621-2986 (online)

\section{PENDAHULUAN}

Stroke merupakan suatu kegawatan yang menyerang pada neurologis secara mendadak yang menjadi salah satu penyebab kecacatan dan kematian tertinggi di dunia (Boger, 2015). Pasien pasca stroke akan mengalami dampak pada aspek fisik, psikologis, sosial, dan spiritual (Bill \& Melinda, 2016). Aspek fisik ditandai dengan terjadinya kelumpuhan semua atau sebagian anggota gerak, kehilangan kemampuan menelan, gangguan komunikasi dan gangguan kognitif. Aspek psikologis ditandai dengan penderita akan mengalami kecemasan, ketakutan, kesedihan, dan putus asa bahkan sampai depresi (Charfi, 2016). Aspek sosial ditandai dengan kehilangan pekerjaan, hambatan dalam menjalankan peran di keluarga maupun masyarakat. Aspek spiritual ditandai dengan menurunnya keimanan untuk melaksanakan kewajiban solat lima waktu dan kurangnya penerimaan diri bahkan sampai menyalahkan Allah SWT (Hidayanti, 2015).

Pasien pasca stroke memiliki beberapa dampak yang dapat menghambat dalam proses penyembuhan. Upaya untuk mencegah serangan stroke berulang, rehospitalisasi dan komplikasi penting bagi penderita untuk memahami pentingnya proses rehabilitasi dan memahami pentingnya pengendalian faktor resiko. Seseorang yang dinyatakan sembuh dari serangan stroke pertama memiliki risiko yang signifikan untuk mengalami serangan stroke yang kedua di kemudian hari dengan risiko kematian lebih tinggi dibandingkan serangan stroke yang pertama. Upaya yang dapat dilakukan untuk mencegah serangan stroke kedua dapat dilakukan dengan menerapkan self care pada pasien (Go AS, 2014).

Self care merupakan upaya untuk mengembangkan sistem kesehatan di mana pasien dan keluarga ikut terlibat dalam perawatan kesehatan pasien. Pasien dan keluarga sebagai mitra dalam membuat keputusan kesehatan dan memastikan bahwa keputusan yang dibuat sejalan dengan tujuan untuk meningkatkan kesehatan dan mempertahankan kehidupan (Barbara, 2017). Self care pada pasien pasca stroke meliputi kepatuhan terhadap pengobatan, pemeliharaan dalam kesehatan fisik (diet, tidak merokok, konsumsi alkohol, konsumsi makanan berkolestrol tinggi), mengelola stress, berkonsultasi dengan tenaga kesehatan dan adanya dukungan sosial untuk melakukan perawatan diri (Camphell, 2007). 
Dampak positif self care pada pasien pasca stroke yaitu dapat meningkatkan aktivitas sehari-hari, kematian, mempermudah kolaborasi, dan meningkatkan kualitas hidup sebesar 95\% dibandingkan dengan perawatan biasa (Barbara, 2017). Self care harus menjadi bagian dari sistem pelayanan kesehatan yang efektif dan efisien. Upaya dalam mencapai hal tersebut perlunya self care yang terlatih dan terorganisasi dengan baik sehingga tercapainya perbaikan dalam perawatan diri di masa mendatang (Camphell, 2007). Tujuan dari penelitian ini untuk mengetahui gambaran self care pada pasien pasca stroke.

\section{METODE}

Penelitian menggunakan metode kuantitatif dengan desain deskriptive survei. Penelitian dilakukan pada bulan Mei 2019 di wilayah kerja Puskesmas Kedungmundu. Teknik sampling dengan pendekatan total sampling sebanyak 79 pasien pasca stroke. Kriteria inklusinya adalah pasien pasca stroke serangan pertama yang masih menjalani rawat jalan dan dapat berkomunikasi dengan baik yang sebelumnya dilakukan dengan pengisian kuesioner SPMSQ (Short Portable Mental Status Questionnaire). Kriteria eksklusinya adalah pasien pasca stroke yang memiliki masalah kognitif. Instrumen penelitian menggunakan kuesioner self care yang terdiri dari 29 item pertanyaan dengan skala dikotomi dan sudah diuji validitas dan reliabilitas oleh Ismayanti (Ismayanti, 2015). Hasil uji reliabilitas 0,971 (>0,6). Penelitian ini mendapatkan ethical clearence di RS. Moewardi dengan nomor 462/IV/HREC/2019. Data penelitian ini dianalisis secara univariat.

\section{HASIL DAN PEMBAHASAN}

\section{A. Hasil Penelitian}

\section{Karakteristik Responden}

Tabel 1. Distribusi Frekuensi Responden berdasarkan Data Karakteristik Responden dan Self Care pada Pasien Paska Stroke di Wilayah Kerja Puskesmas Kedungmundu Mei $2019(n=79)$

\begin{tabular}{lcccc}
\hline \multirow{2}{*}{ Karakteristik Responden } & \multicolumn{2}{c}{ Kategori Self Care } & \multirow{2}{*}{$\begin{array}{c}\text { Total } \\
n\end{array}$} \\
\cline { 2 - 4 } & & Baik & Kurang & $n(\%)$ \\
\hline \multirow{3}{*}{ Usia } & Dewasa Akhir & $2(66,7 \%)$ & $1(33,3 \%)$ & $3(100 \%)$ \\
\cline { 2 - 4 } & Lansia Awal & $10(55,6 \%)$ & $8(44,4 \%)$ & $18(100 \%)$ \\
\cline { 2 - 4 } & Lansia Akhir & $33(56,9 \%)$ & $25(43,1 \%)$ & $58(100 \%)$ \\
\hline
\end{tabular}


Jurnal Ilmu Keperawatan Medikal Bedah 3 (1), Mei 2020, 1-76

ISSN 2338-2058 (print), ISSN 2621-2986 (online)

\begin{tabular}{ccccc}
\hline Jenis Kelamin & Laki-laki & $23(62,2 \%)$ & $14(37,8 \%)$ & $37(100 \%)$ \\
\cline { 2 - 5 } & Perempuan & $22(52,4 \%)$ & $20(47,6 \%)$ & $42(100 \%)$ \\
\hline Status & Menikah & $38(64,4 \%)$ & $21(35,6 \%)$ & $59(100 \%)$ \\
\cline { 2 - 5 } Perkawinan & Duda/Janda & $7(35 \%)$ & $13(65 \%)$ & $20(100 \%)$ \\
\hline \multirow{3}{*}{$\begin{array}{c}\text { Tingkat } \\
\text { Pendidikan }\end{array}$} & Tidak Sekolah & $13(54,2 \%)$ & $11(45,8 \%)$ & $24(100 \%)$ \\
\cline { 2 - 5 } & SD & $17(54,8 \%)$ & $14(45,2 \%)$ & $31(100 \%)$ \\
\cline { 2 - 5 } & SMP & $4(80 \%)$ & $1(20 \%)$ & $5(100 \%)$ \\
\cline { 2 - 5 } & SMA & $8(57,1 \%)$ & $6(42,9 \%)$ & $14(100 \%)$ \\
\cline { 2 - 5 } & Perguruan & $3(60 \%)$ & $2(40 \%)$ & $5(100 \%)$ \\
\hline Lama Stroke & Tinggi & & & \\
& $0-6$ bulan & $6(54,5 \%)$ & $5(45,5 \%)$ & $11(100 \%)$ \\
\cline { 2 - 5 } & $7-12$ bulan & $18(72 \%)$ & $7(28 \%)$ & $25(100 \%)$ \\
\cline { 2 - 5 } & $>1$ tahun & $21(48,8 \%)$ & $22(51,2 \%)$ & $43(100 \%)$ \\
\hline
\end{tabular}

Tabel 1 menunjukkan sebagian besar responden paska stroke yaitu lansia akhir $(73,4 \%)$, berjenis kelamin perempuan $(53,2 \%)$, status perkawinan menikah $(74,7 \%)$ dengan tingkat pendidikan SD (39,2\%), serta menderita stroke selama $>1$ tahun.

\section{Gambaran Self Care Pada Pasien Paska Stroke}

Tabel 2. Distribusi Frekuensi Responden berdasarkan Data Karakteristik Responden Gambaran Self Care di Wilayah Kerja Puskesmas Kedungmundu Mei 2019 ( $n=79)$

\begin{tabular}{ccc}
\hline Kategori Self Care & Frekuensi & Persentase $(\%)$ \\
\hline Self care baik & 45 & $57 \%$ \\
Self care kurang & 34 & $43 \%$ \\
\hline Total & 79 & $100 \%$ \\
\hline
\end{tabular}

Tabel 2 menunjukkan gambaran self care pada pasien pasca stroke dalam kategori self care baik lebih dari separuh (57\%). Namun, ada sebagian responden yang memiliki self care kurang baik (43\%).

Tabel 3. Distribusi Frekuensi Responden berdasarkan Sebaran Item Pertanyaan Kuesioner Self Care pada Pasien Pasca Stroke di Wilayah Kerja Puskesmas Kedungmundu Mei $2019(n=79)$

\begin{tabular}{llcc}
\hline & \multicolumn{1}{c}{ Item Pertanyaan } & Ya & Tidak \\
\hline 1) & Apakah Anda memiliki masalah dengan pernapasan (seperti asma, & 15 & 64 \\
& sesak napas, batuk, dll)? & $(19 \%)$ & $(81 \%)$ \\
\hline 2) & Apakah Anda merokok? & 10 & 69 \\
& & $(12,7 \%)$ & $(87,3 \%)$ \\
\hline 3) & Apakah Anda minum 8-10 gelas air putih setiap hari? & 54 & 25 \\
& & $(68,4 \%)$ & $(31,6 \%)$ \\
\hline 4) & Apakah Anda pernah mengalami kesulitan makan, mengunyah, & 14 & 65 \\
& atau menelan? & $(17,7 \%)$ & $(82,3 \%)$ \\
\hline 5) & Apakah Anda memerlukan bantuan untuk BAK (buang air kecil) \\
& maupun BAB (buang air besar)? & 19 & 60 \\
& & $(24,1 \%)$ & $(75,9 \%)$ \\
\hline
\end{tabular}


Jurnal Ilmu Keperawatan Medikal Bedah 3 (1), Mei 2020, 1-76

ISSN 2338-2058 (print), ISSN 2621-2986 (online)

6) Apakah Anda mengalami masalah dengan BAK seperti terasa sakit $4 \quad 45$ perut?

7) Apakah Anda pernah mengalami masalah diare atau sakit perut?

$(5,1 \%) \quad(94,9 \%)$

8) Apakah Anda mandi teratur 2 kali dalam sehari?

$(6,3 \%) \quad(93,7 \%)$

$69 \quad 10$

$(87,3 \%) \quad(12,7 \%)$

9) Apakah Anda dan keluarga rajin membersihkan lingkungan tempat $\quad 56 \quad 23$ tinggal Anda (seperti menyapu, mengepel, dll)?

10) Apakah Anda sering berolahraga? $(70,9 \%) \quad(29,1 \%)$

$55 \quad 24$

$(69,6 \%) \quad(30,4 \%)$

11) Apakah Anda pernah mengalami susah tidur?

$24 \quad 55$

$(30,4 \%) \quad(69,6 \%)$

12) Apakah Anda memerlukan bantuan orang lain dalam melakukan $20 \quad 59$ aktivitas sehari-hari?

$(25,3 \%) \quad(74,7 \%)$

13) Apakah Anda selalu berkomunikasi/berbicara dengan anggota $72 \quad 7$ keluarga setiap harinya?

14) Apakah Anda merasa kesepian?

$(91,1 \%) \quad(8,9 \%)$

$22 \quad 57$

$(27,8 \%) \quad(72,2 \%)$

15) Apakah Anda sering mengikuti kegiatan di lingkungan Anda? $\quad 40 \quad 39$

$(50,6 \%) \quad(49,4 \%)$

16) Apakah Anda memiliki teman dekat selain keluarga? $\quad 55 \quad 24$

17) Apakah Anda mengetahui bahaya dari penyakit Anda?

$(69,6 \%) \quad(30,6 \%)$

18) Apakah Anda memeriksa kesehatan secara teratur?

$(67,1 \%) \quad(32,9 \%)$

\begin{tabular}{lcc}
$19)$ & $(67,1 \%)$ & $(32,9 \%)$ \\
\hline
\end{tabular}

\begin{tabular}{lcc} 
& $(35,4 \%)$ & $(64,6 \%)$ \\
\hline
\end{tabular}

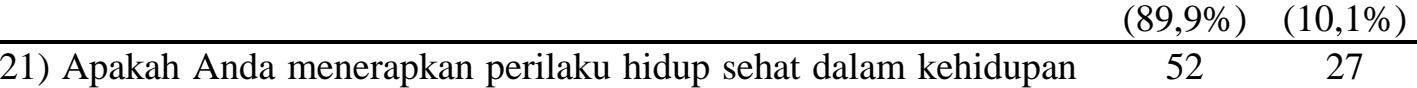
sehari-hari Anda?

22) Apakah Anda mengalami kesulitan dalam mengingat?

$(65,8 \%) \quad(34,2 \%)$

\begin{tabular}{lcc} 
& $(15,2 \%)$ & $(84,8 \%)$ \\
\hline
\end{tabular} biasa?

$(53,2 \%) \quad(46,8 \%)$

24) Apakah Anda yakin dengan pengobatan yang Anda jalani?

$63 \quad 16$

$(79,7 \%) \quad(20,3 \%)$

25) Apakah keluarga mendukung Anda dalam melakukan aktivitas $75 \quad 3$ sehari-hari?

$(94,9 \%) \quad(3,8 \%)$

26) Apakah Anda dapat mengontrol emosi untuk kesembuhan Anda? $\quad 68 \quad 11$ $(86,1 \%) \quad(13,9 \%)$

27) Apakah Anda memiliki keinginan untuk berkumpul bersama teman $\quad 72 \quad 7$ Anda?

28) Apakah Anda selalu mengontrol ke rumah sakit sesuai jadwal? $(91,1 \%) \quad(8,9 \%)$

\begin{tabular}{lcc} 
& $(60,8 \%)$ & $(39,2 \%)$ \\
\hline
\end{tabular}

$(97,5 \%) \quad(2,5 \%)$

Tabel 3 menunjukkan beberapa item self care responden kurang baik. Hal tersebut didapatkan dari hasil pada tabel bahwa terdapat responden yang tidak mengikuti 
kegiatan di lingkungan yaitu sebanyak 39 responden (49,4\%), responden yang memiliki perasaan takut, marah, kecewa sebanyak 28 responden (35,4\%), responden yang tidak menerapkan perilaku hidup bersih sehat dalam kehidupan sehari-hari sebanyak 27 responden $(34,2 \%)$, pernah mengalami susah tidur sebanyak 24 responden $(30,4 \%)$, dan responden yang mengalami kesepian sebanyak 22 responden $(27,8 \%)$.

\section{B. Pembahasan}

Hasil penelitian menunjukkan sebagian besar memiliki self care yang baik yaitu sebanyak 45 responden (57\%). Penelitian yang sejalan menyatakan bahwa self care yang baik yaitu sebanyak 75\% (Ismatika, 2017). Self care yang baik dikarenakan pasien memiliki keyakinan diri yang baik. Teori sosial kognitif yang menyatakan bahwa dengan memiliki keyakinan diri yang baik dapat memberikan motivasi dalam melakukan aktivitas sehari-hari secara mandiri, membantu pemulihan motorik, meningkatkan kepercayaan diri, serta pasien akan memiliki tingkat stress yang rendah (Rustika, 2012).

Self care merupakan upaya untuk mengembangkan sistem kesehatan yang melibatkan pasien dan keluarga dalam perawatan kesehatannya. Pasien dan keluarga sebagai mitra dalam pembuatan keputusan dengan tujuan meningkatkan kesehatan dan mempertahankan kehidupan. Self care pada pasien stroke dapat meningkatkan aktivitas sehari-hari, mengurangi ketergantungan, mengurangi beban gaya hidup akibat penyakit, kematian dini pada pasien pasca stroke, serta meningkatkan kualitas hidup sebesar 95\% dibandingkan dengan perawatan biasa (Barbara, 2017). Self care dapat dilakukan dengan efektif dan efisien maka akan meminimalisir terjadinya kecacatan bahkan mengurangi kematian (Patricia, 2005).

Self care baik sebagian besar terjadi pada usia baik dewasa akhir, lansia awal, dan lansia akhir. Faktor umur dapat mempengaruhi, semakin cukup umur tingkat kematangan seseorang maka lebih matang dalam berfikir dan bekerja (Dewi, 2010). Individu memiliki pengalaman yang banyak sehingga dapat digunakan untuk menyelesaikan permasalahan dengan mencapai tujuan yang diinginkan seperti individu mampu mempertahankan dan meningkatkan kesehatannya. Self care yang 
baiksebagian besar juga terjadi pada jenis kelamin laki-laki daripada perempuan. Penelitian yang sejalan menyatakan bahwa jenis kelamin laki-laki memiliki stressor yang lebih baik dibandingkan perempuan (Zalihic, 2010). Laki-laki lebih tenang dalam menghadapi sesuatu dan mudah bergaul sehingga pada laki-laki dapat mencari solusi dalam menyelesaikan masalah melalui bertukar pikiran dengan orang lain, sedangkan perempuan emosinya cenderung lebih mendominasi dan memiliki banyak fokus seperti mengurus anak, rumah tangga, maupun pekerjaaan, dimana hal ini dapat menimbulkan perasaan cemas dan mengabaikan perawatan dirinya (Devi, 2007).

Karakteristik responden dengan status perkawinan sebagian besar self care yang baik berada pada responden yang sudah menikah yaitu 38 orang $(64,4 \%)$. Self care akan menjadi lebih baik jika memiliki hubungan dan dukungan positif dari pasangannya. Pasangan dapat menjadi sumber motivasi bagi pasien yang melaksanakan self care (Irwan, 2016). Karakteristik responden dengan pendidikan baik tidak sekolah, SD, SMP, SMA, maupun perguruan tinggi juga sebagian besar memiliki self care yang baik. Proporsi tertinggi pada responden yang berpendidikan SD yaitu sebanyak 17 orang $(54,8 \%)$. Individu dapat memanfaatkan perkembangan teknologi yang semakin canggih seperti saat ini, semua orang dapat dengan mudah mengakses jaringan internet termasuk orang yang berpendidikan rendah. Orang yang berpendidikan rendah meskpun tidak mengikuti pendidikan formal, mereka dapat memperoleh informasi dengan mudah sehingga hal ini dapat meningkatkan self care pada individu.

Penelitian ini juga didapatkan hasil self care yang kurang baik yaitu sebanyak 34 responden (43\%). Penelitian ini sejalan dengan penelitian Ismayanti yang menyatakan bahwa sebanyak 33 responden $(52,4 \%)$ memiliki self care yang kurang baik. Self care yang kurang baik dikarenakan kondisi fisiknya yang menurun akibat adanya manifestasi dari stroke. Keterbatasan fisik pada stroke dapat menyebabkan ketergantungan terhadap orang lain dalam menjangkau layanan kesehatan (Ismayanti, 2015). Middle range theory of chronic illness yang menyatakan bahwa dalam mencapai kemampuan untuk melakukan perawatan diri diperlukan adanya 
motivasi, keyakinan budaya, kebiasaan, keyakinan diri, harga diri, dukungan sosial, dan fasilitas (Riegel, 2012).

Pasien paska stroke selama $>1$ tahun memiliki self care kurang baik yaitu sebanyak 22 responden $(51,2 \%)$. Penelitian lain juga menyatakan bahwa individu yang telah lama terdiagnosis stroke akan mengalami kelelahan fisik dan emosional, dimana hal ini yang menurunkan produktivitas dalam melakukan perawatan diri (Milazzo, 2014). Semakin lama menderita stroke maka individu akan mengalami kejenuhan dalam melakukan rehabilitasi yang panjang. Kejenuhan dapat meningkatkan bebas psikis yang dapat menyebabkan stress sehingga dapat menghambat dalam melakukan perawatan diri (Wardhana, 2011).

Self care yang kurang baik didapatkan hasil bahwa terdapat responden yang tidak mengikuti kegiatan di lingkungan yaitu sebanyak 39 responden $(49,4 \%)$. Penelitian lain juga menyatakan bahwa sebanyak 34 responden memiliki hubungan dengan lingkungan yang kurang memiliki self care yang kurang yaitu sebanyak 27 responden $(79,4 \%)$ (Ismayanti, 2015). Adanya hambatan mobilitas fisik pada pasien stroke akibat manifestasi dari stroke sehingga kurangnya motivasi untuk melakukan kegiatan di lingkungan. Hambatan ini juga menyebabkan responden tidak dapat melakukan tugas dalam keluarga seperti biasa yaitu sebanyak 37 responden (46,8\%). Penelitian yang sejalan menyatakan bahwa sebanyak 19 responden $(55,9 \%)$ mengalami penurunan mobilitas sehingga responden tidak dapat melakukan aktivitas sehari-hari. Hambatan mobilitas ini mengakibatkan terjadinya perubahan aktivitas sehari-hari, aktivitas kerja maupun hubungan sosial. Pasien tidak dapat bekerja kembali seperti sediakala dan sosialisasinya dapat juga terhambat akibat sebagian dari tubuhnya mengalami kecacatan (Juliana, 2012).

Self care kurang baik pada responden yang memiliki perasaan takut, marah, kecewa sebanyak 28 responden $(35,4 \%)$. Penderita stroke cenderung mengalami emosi yang negatif seperti takut, marah, kecewa. Risiko stroke tiga kali lipat meningkat saat emosi negatif muncul (Wardhana, 2011). Pasien pasca stroke mudah sekali mengalami ketidakstabilan emosi akibat kelumpuhan dan penurunan kemampuan fisiknya. Emosi yang tidak stabil berakibat buruk bagi kesehatan penderita stroke (Aditya \& Handayani, 2012). Emosi negatif dapat menyebabkan 
denyut jantung menjadi cepat dan pembuluh darah cenderung menyempit sehingga tekanan darah meningkat, dimana hal ini merupakan salah satu dari faktor risiko terjadinya stroke.

Responden tidak menerapkan perilaku hidup bersih sehat dalam kehidupan sehari-hari sebanyak 27 responden (34,2\%). Pola makan yang baik memiliki risiko terkena stroke lebih kecil daripada tidak menjaga pola makan yang baik. Individu yang menjaga pola makan akan meminimalisir untuk mengkonsumsi makanan yang mengandung kolestrol. Aktivitas menjaga pola makan yang baik harus diimbangi dengan olahraga rutin. Penelitian ini menyatakan bahwa responden tidak melakukan olahraga rutin sebanyak 24 responden (30,4\%). Aktivitas fisik seperti olahraga dapat menurunkan risiko terkena stroke. Olahraga juga dapat menurunkan tekanan darah, memperbaiki kebiasaan makan dan menurunkan efek biologis dari olahraga yaitu penurunan aktivitas platelet, reduksi fibrinogen plasma dan menahan konsentrasi HDL sehingga dapat mencegah terjadinya pembekuan darah dan plak pada pembuluh darah dimana hal tersebut dapat menyebabkan risiko stroke (Gafarov, 2015).

Penelitian ini juga menemukan bahwa responden pernah mengalami susah tidur sebanyak 24 responden (30,4\%). Penelitian yang sejalan menyatakan bahwa sebanyak 45,5\% responden mengalami kualitas tidur yang buruk (Wardhana, 2011). Gangguan tidur memiliki risiko infark miokard sebesar 2-2,6 kali lebih tinggi dan risiko stroke sebesar 1,5-4 kali lebih tinggi daripada seseorang yang tidak memiliki gangguan tidur atau dengan kualitas tidur yang baik. Tidur berfungsi untuk mempertahankan fungsi fisiologis, psikologi, memori, regulasi hormon dan aktivitas sistem imun sehingga apabila hal tersebut dapa terkontrol dengan baik akan meningkatkan kesehatan bagi individu. Penelitian ini diketahui bahwa mayoritas responden yaitu usia lansia akhir dimana pada usia ini cenderung mengalami kebiasaan durasi tidur yang pendek. Durasi tidur yang pendek dapat mengakibatkan hormon pengaturan keseimbangan tekanan darah tidak bekerja secara optimal, sehingga kehilangan waktu tidur dapat membuat sistem saraf menjadi hiperaktif yang kemudian mempengaruhi sistem seluruh tubuh termasuk 
jantung dan pembuluh darah. Durasi tidur yang pendek ini apabila tidak segera ditangani dapat menyebabkan risiko stroke (Xia Ning, 2018).

Responden pada penelitian ini mengalami kesepian sebanyak 22 responden $(27,8 \%)$. Penelitian sebelumnya menyatakan bahwa kesepian dapat mempengaruhi kondisi kesehatan. Individu yang kesepian memiliki risiko stroke 36\% lebih tinggi daripada yang mendapat dukungan keluarga (Ning Xia, 2018). Penelitian lain juga menyatakan bahwa 87,8\% responden mendapatkan dukungan keluarga dalam menjalani rehabilitasi (Mutia, 2014). Dukungan keluarga dibutuhkan untuk kesembuhan penderita pasca stroke yang menjalani rehabilitasi (Lis \& Handayani, 2018). Keluarga mempunyai peran penting dalam memelihara dan meningkatkan kesehatan serta membantu keberhasilan pengobatan (Rosmary \& Handayani, 2019). Dukungan keluarga dapat diberikan dalam bentuk memberikan semangat, motivasi, memenuhi kebutuhan sehari-hari dan dorongan kepada penderita agar dapat menerima kondisi dan berusaha dengan kuat untuk sembuh (Harahap, 2015). Adanya dukungan ini membuat rasa percaya diri dan motivasi untuk menghadapi masalah akan meningkat.

\section{KESIMPULAN}

Sebagian besar responden paska stroke yaitu lansia akhir $(73,4 \%)$, berjenis kelamin perempuan $(53,2 \%)$, status perkawinan menikah $(74,7 \%)$ dengan tingkat pendidikan SD $(39,2 \%)$, serta menderita stroke selama $>1$ tahun. Gambaran self care pada pasien pasca stroke dalam kategori self care baik lebih dari separuh (57\%). Namun, ada sebagian responden yang memiliki self care kurang baik (43\%). Individu diharapkan dapat mempertahankan self care yang baik. Keluarga juga diharapkan untuk memotivasi pasien dalam melakukan self care. Puskesmas dapat melakukan kunjungan ke rumah pasien pasca stroke untuk memonitor kemajuan kesehatannya. Institusi diharapkan dapat mengadakan kegiatan pengabdian masyarakat kepada pasien pasca stroke. Peneliti selanjutnya dapat melakukan penelitian terkait faktor-faktor yang mempengaruhi self care pada pasien pasca stroke. 
Jurnal Ilmu Keperawatan Medikal Bedah 3 (1), Mei 2020, 1-76

ISSN 2338-2058 (print), ISSN 2621-2986 (online)

\section{DAFTAR PUSTAKA}

Adientya G \& Handayani F. (2012). Stres pada kejadian stroke. Jurnal Nursing Studies.1 (1):183-8.

Barbara R. (2017). Self-care for the prevention and management of cardiovascular disease and stroke a scientific statement for healthcare professionals from the American Heart Association. Journal American Heart Association: 118 .

Bill \& Melinda Gates Foundation. (2016). New Study: Indonesia faces a "double burden" of diseases. The Lanchet.

Boger, E.J., Hankins, M., Demain, S.H., Latter, S.M., et al. (2015). Development and psychometric evaluation of a new patient-reported outcome measure for stroke self-management: The Southampton Stroke Self-Management Questionnaire (SSSMQ). Health Quality of Life Outcomes: 1-9.

Camphell, J. (2007). Supporting self-care in general practice. British Journal General Practice: 57.

Charfi, Trabelsi, S., Turki, M., Mâalej Bouali, M., Zouari, L., Dammak, M., Ben Thabet, J., Mhiri, C., Mâalej, M., et al. (2016). Impact of physical disability and concomitant emotional disturbances on post-stroke quality of life (43(5):429-434).

Devi, S. (2007). Perbedaan komitmen kerja berdasarkan orientasi pada gender. Universitas Gunadarma.

Dewi, W. (2010). Teori dan pengukuran pengetahuan, sikap, dan perilaku manusia. Yogyakarta: Nuha Medika.

Gafarov, D., Panov, Gromova, Gagulin, A.G. (2015). Relations of sleep disturbances with psychosocial factors in female population aged 25-64 years in Russia: Monica-Psychosocial Epidemiological Study.

Go, A.S., Mozaffarian, D., Roger, V.L., Benjamin, E.J., Berry, J.D., Blaha, M.J., et al. (2014). Heart disease and stroke statistics--2014 update: a report from The American Heart Association. Circulation (21;129(3):e28-e292).

Harahap, S. (2015). Hubungan kemampuan fungsi tubuh dan dukungan keluarga dengan depresi pada pasien pasca stroke. Jurnal Kesehatan USU.

Hidayanti, E. (LP2M UW). (2015). Representasi nilai-nilai Islam dalam pelayanan kesehatan: studi terhadap Husnul Khatimah Care (Hucare) bagi pasien rawat inap di Rumah Sakit Nur Hidayah Yogyakarta: 78-80.

Irwan, A.M., Mayumi, K., Kazuyo, K., Teruhiko, K.Y.T.M. (2016). Factors of selfcare practices and health-seeking behavior among older persons in a developing country: theories-based research. Elsevier International Journal Nurse Science: $1-11$.

Ismatika, U.S. (2017). Hubungan self efficacy dengan perilaku self care pasien pasca stroke di Rumah Sakit Islam Surabaya. 
Ismayanti, D. (2015). Hubungan kualitas hidup pasien stroke dengan perawatan diri (self care) di Poliklinik Saraf Rumah Sakit Umum Daerah Dr Zainoel Abidin Banda Aceh.

Juliana. (2012). Quality of life pasien pasca stroke di Ruang Rehabilitasi Medis Rumah Sakit Umum Zainoel Abidin Banda Aceh.

Lis, M.L., \& Handayani, F. (2018). Pengaruh pengelolaan stress keluarga terhadap Activity Daily Living (ADL) pasien post stroke iskemik: literature review. Jurnal Ilmu Keperawatan Medical Bedah 2.

Milazzo. (2014). Are you way too stressed out? survey results. An Assessment of The Stress Levels of Nurses in The United States. Vickie Milazzo Institute.

Mutia, S. (2014). Dukungan keluarga pada pasien paska stroke dalam menjalani terapi rehabilitasi di RS Haji Medan. Jurnal Kesehatan USU.

Ning Xia \& Huige. (2018). Loneliness, social isolation, and cardiovascular health (28(9): 837-851). Available from: https://litbang.kemendagri.go.id/website/menurut-penelitian-kesepian buruk-untuk-kesehatan-jantung/.

Patricia, A.P. (2005). Fundamental of nursing : concept, process, and practice. Jakarta: Buku Kedokteran EGC.

Riegel, B. (2012). A middle range theory of self care science (chronic illness). Nursing (Lond) (35), 3, 194-204.

Rosmary, M., \& Handayani, F. (2019). Hubungan pengetahuan keluarga dan perilaku keluarga pada penanganan awal kejadian stroke. Available from: http://eprints.undip.ac.id/73648/.

Rustika, I.M. (2012). Efikasi diri: tinjauan teori Albert Bandura. Buletin Psikologi Vol. 20, No.1-2. Yogyakarta: Fakultas Psikologi Universitas Gadjah Mada.

Wardhana, W.A. (2011). Strategi mengatasi dan bangkit dari stroke: panduan bagi penderita, keluarga, sahabat, dan siapa saja yang peduli terhadap stroke. Yogyakarta: Pustaka Pelajar (Cetakan 1).

Zalihic, A., Marotic, Vedran, Zalihic, D., Mabic, Mirela, et al. (2010). Gender and quality of life after cerebral stroke. Bosn Jurnal Basic Medical Science. 